Cite this: RSC Adv., 2014, 4, 25809

\title{
Well-defined ABA- and BAB-type block copolymers of PDMAEMA and PCL $\uparrow$
}

\author{
Carl Bruce, ${ }^{a}$ Irakli Javakhishvili, ${ }^{\mathrm{b}}$ Linda Fogelström, ${ }^{a}$ Anna Carlmark, ${ }^{a}$ Søren Hvilsted ${ }^{\text {b }}$ \\ and Eva Malmström*a
}

Triblock copolymers of ABA- and BAB-type consisting of poly(2-(dimethylamino)ethyl methacrylate) (PDMAEMA, A) and poly( $\varepsilon$-caprolactone) (PCL, B) have successfully been prepared. PDMAEMA- $b-P C L-b-$ PDMAEMA (ABA) and PCL-b-PDMAEMA- $b-P C L$ (BAB) were synthesised by a combination of ringopening polymerisation of $\varepsilon-\mathrm{CL}$, atom transfer radical polymerisation of DMAEMA and end-group conversion, performed through either acylation or azide-alkyne "click" chemistry. All samples were analysed by size exclusion chromatography where it was found that the evaluation of PDMAEMAcontaining polymers was difficult due to the thermoresponsivity of PDMAEMA, affecting the solubility of the polymer in the temperature range at which the SEC was operated. From differential scanning calorimetry measurements it was shown that the crystallinity could be altered by changing the order of the blocks; with PDMAEMA as the outer block (ABA), the inherent crystallinity of PCL was destroyed while with $P C L$ as the outer block (BAB), the degree of crystallinity was in the same proximity as for a PCL homopolymer.

Received 19th February 2014

Accepted 4th June 2014

DOI: $10.1039 / c 4 r a 04325 a$

www.rsc.org/advances encapsulate and transport, and subsequently also release, compounds, such as in drug delivery. ${ }^{15-17}$ Micelles also have the ability to alter their functionality and/or the surface energy of a substrate through adsorption, an approach which has attracted increasing attention lately. ${ }^{18,19}$

For water-based applications, there are several options for the hydrophilic block as reported previously in literature, such as: poly(ethylene glycol) (PEG), ${ }^{20}$ poly(acrylic acid), ${ }^{21}$ and $\operatorname{poly}(N$ isopropyl acrylamide) (PNIPAAm). ${ }^{22}$ One polymer that has gained attention due to its facile synthesis by ATRP, as well as due to the fact that it can carry a permanent cationic charge, is poly(2-(dimethylamino)ethyl methacrylate) (PDMAEMA). Several reports describe the ability of PDMAEMA to enable micellar formation in combination with a suitable hydrophobic block. ${ }^{23-28}$ However, PDMAEMA is prone to hydrolysis, wherefore its quaternised form, i.e., with a permanent charge, is preferred in water-based applications. ${ }^{29}$

In this study, triblock copolymers of PDMAEMA and poly( $\varepsilon$-caprolactone) (PCL) have been synthesised. The PDMAEMA block was synthesised through ATRP and the PCL block through Ring-Opening Polymerisation (ROP) of $\varepsilon$-caprolactone ( $\varepsilon$-CL). ROP is a suitable method for polymerisation of cyclic lactones and, as ATRP, yields well-defined polymers of low $\bigoplus_{\mathrm{M}} \cdot{ }^{30} \mathrm{PCL}$ is a biodegradable polymer previously used in a variety of applications such as medical ${ }^{31-33}$ and biocomposites. ${ }^{34-36}$ Block copolymers of PDMAEMA and PCL have previously been reported, mainly in the form of diblock copolymers, where different synthetic routes have been evaluated. ${ }^{37-39}$ However, the work on triblock copolymers of PDMAEMA and PCL is to a more limited
${ }^{a}$ KTH Royal Institute of Technology, School of Chemical Science and Engineering, Department of Fibre and Polymer Technology, Teknikringen 56-58, SE-100 44 Stockholm, Sweden.E-mail: mavem@kth.se

${ }^{b}$ Technical University of Denmark, Department of Chemical and Biochemical Engineering, Danish Polymer Centre, Building 227, DK-2800 Kgs Lyngby, Denmark $\dagger$ Electronic supplementary information (ESI) available: HSQC NMR spectrum of HO-PDMAEMA-OH, MALDI-TOF spectra of HO-PDMAEMA-OH and Br-PCL-Br, and DLS measurements of triblock copolymers. See DOI: 10.1039/c4ra04325a 
extent reported in literature. ${ }^{\mathbf{4 0 , 4 1}}$ Additionally, the reports on triblocks of PDMAEMA and PCL are, to the authors' best knowledge, limited to ABA type triblocks where PCL composes the middle block, i.e., B. In this work, the focus has been to synthesise well-defined ABA- and BAB-type triblocks of PDMAEMA and PCL, where PCL is B and PDMAEMA is A. In a long-term perspective it is interesting to evaluate both types of triblocks, ABA and $\mathbf{B A B}$, as compatibilisers in cellulose-reinforced biocomposites.

Cellulose is the most abundant biopolymer in the world..$^{42}$ In addition to being both biobased and biodegradable, cellulose fibres exhibit good mechanical properties, have a high aspect ratio and relatively low density. ${ }^{\mathbf{4 3}}$ Cellulose fibres are therefore a good alternative to fossil-based fibres in composites. However, due to the hydrophilic nature of cellulose, the compatibility with many polymer matrices is poor and a modification is, therefore, desirable to perform in order to solve the compatibility issue. ${ }^{\mathbf{4 4 , 4 5}} \mathbf{A B A}$ and $\mathbf{B A B}$ triblocks would be two new types of compatibilisers for cellulose-reinforced composites. ABA triblocks can potentially form links between cellulose fibres or loops on one single fibre and $\mathbf{B A B}$ triblocks can theoretically form entanglements together with a polymeric matrix material and/or with other BAB or ABA block copolymers adsorbed. Hence, the development and optimisation of the synthesis of both types of triblocks are of interest. In this study the purpose is to, in a more fundamental approach, synthesise both types of triblocks for future evaluations in a final composite. The chemical approaches utilised herein were combinations of ATPR, ROP, end-group transformation through either acylation of a terminal hydroxyl group into an ATRP-initiator or of a terminal halide to an azide ${ }^{\mathbf{4 6}}$ and Huisgen 1,3-dipolar cycloaddition reaction between alkynes and azides ${ }^{\mathbf{4 7}}$ in its modified form, the $\mathrm{Cu}(\mathrm{I})$-catalysed azide-alkyne "click" reaction. ${ }^{48}$

\section{Experimental}

\section{Materials}

All chemicals were purchased from Aldrich unless stated otherwise.

2-(Dimethylamino)ethyl methacrylate (DMAEMA, 98\%) was passed through a basic $\mathrm{Al}_{2} \mathrm{O}_{3}$ column prior to use to remove the inhibitor. $\varepsilon$-Caprolactone ( $\varepsilon$-CL, 99\%, Alfa Aesar) was dried over $\mathrm{CaH}_{2}$ overnight, distilled under reduced pressure, and stored under argon at $4{ }^{\circ} \mathrm{C}$. Toluene (HPLC grade, Fischer Scientific) was dried through azeotropic boiling prior to use. 2-Hydroxyethyl bromoisobutyrate (HEBI, 95\%), $\alpha$-bromoisobutyryl bromide (BiB, 98\%), 4-(dimethyloamino)pyridine (DMAP, 99+\%), 1,1,4,7,10,10-hexamethyltriethylenetetramine (HMTETA, 97\%), $N, N, N^{\prime}, N^{\prime \prime}, N^{\prime \prime}$-pentamethyldiethylenetriamine (PMDETA, 99\%), propargyl alcohol (99\%), copper chloride (Cu(I)Cl, $(99+\%))$, copper bromide $(\mathrm{Cu}(\mathrm{I}) \mathrm{Br},(98 \%))$, copper(II) bromide $\left(\mathrm{Cu}(\mathrm{II}) \mathrm{Br}_{2}(99 \%)\right)$, tin octoate $\left(\mathrm{Sn}(\mathrm{Oct})_{2}, 95 \%\right)$, sodium azide $\left(\mathrm{NaN}_{3}, 99+\%\right)$, Sephadex G50 (medium), methyl iodide (MeI, 99\%, Lancaster), sodium hydroxide pellets ( $\mathrm{NaOH}, 98 \%)$, trimethylsilyldiazomethane solution (2 $\mathrm{M}$ in diethyl ether), hydrochloric acid ( $\mathrm{HCl}, 37 \%)$, acetone (Prolabo, technical), methanol ( $\mathrm{MeOH}$, Merck), $N, N$-dimethylformamide (DMF,
VWR), tetrahydrofuran (THF, Merck), and dichloromethane (DCM, Merck) were all used as received.

\section{Methods}

Nuclear magnetic resonance (NMR) spectra were recorded with a Bruker Avance $400 \mathrm{MHz}$ using deuterated chloroform $\left(\mathrm{CDCl}_{3}\right)$ as solvent. The residual solvent signal was used as the internal standard.

To determine molecular weight $\left(M_{\mathrm{n}}\right)$, molar-mass dispersity $\left(\oslash_{\mathrm{M}}\right)$ and monitor ROP reactions, two size exclusion chromatography (SEC) systems were used: (1) TOSOH EcoSEC HLC8320GPC system equipped with an EcoSEC RI detector and three columns (PSS PFG $5 \mu \mathrm{m}$; Microguard, $100 \AA$ and $300 \AA$ ) $\left(M_{\mathrm{w}}\right.$ resolving range: $\left.300-100000 \mathrm{Da}\right)$ from PSS GmbH utilising DMF $\left(0.2 \mathrm{~mL} \mathrm{~min}^{-1}\right.$ ) with $0.01 \mathrm{M} \mathrm{LiBr}$ as the mobile phase at $50{ }^{\circ} \mathrm{C}$. A conventional calibration method was created using narrow molecular-weight distribution linear poly(methyl methacrylate) standards ( $M_{\mathrm{w}}$ range: $\left.400-300000 \mathrm{Da}\right)$. The flowrate fluctuations were corrected using toluene as an internal standard. PSS WinGPC software version 7.2 was used to process the data. (2) Viscotek 200 instrument using two PLgel mixed-D columns (Polymer Laboratories (PL)), assembled in series, and a refractive index detector, utilising THF $\left(1 \mathrm{~mL} \mathrm{~min}^{-1}\right)$ as the mobile phase operating at room temperature. Molecular weights were calculated using polystyrene (PS) standards from PL using TriSEC software.

Fourier transform infrared (FTIR) spectra were recorded on a Perkin-Elmer Spectrum 100 FTIR equipped with a MKII Golden Gate $^{\mathrm{TM}}$, Single Reflection ATR System from Specac Ltd, London, UK. The ATR-crystal was a MKII heated Diamond $45^{\circ} \mathrm{C}$ ATR Top Plate.

The thermal properties of the polymers were analysed with differential scanning calorimetry (DSC). The experiments were performed with a Mettler-Toledo DSC with Mettler Toledo STARe software v9.2 equipped with a sample robot and a cryocooler. The heating and cooling rates were $10{ }^{\circ} \mathrm{C} \mathrm{min}^{-1}$ in the temperature range of $-70{ }^{\circ} \mathrm{C}$ to $180{ }^{\circ} \mathrm{C}$. The degree of crystallinity $\left(X_{\mathrm{c}}\right)$ was calculated according to:

$$
X_{\mathrm{c}}=\frac{\Delta H_{\mathrm{c}}}{\Delta H_{100}^{\circ}}
$$

where $\Delta H_{\mathrm{c}}$ is the heat of crystallisation of the sample and $\Delta H_{100}^{\circ}$ is the heat of crystallisation of $100 \%$ crystalline PCL, which has a value of $136.4 \mathrm{~J} \mathrm{~g}^{-1} \cdot{ }^{49}$ In a block copolymer where the blocks are miscible, the weight fractions of the different components can be calculated according to Fox equation: ${ }^{50}$

$$
\frac{1}{T_{\mathrm{g}}}=\frac{w_{1}}{T_{\mathrm{g} 1}}+\frac{w_{2}}{T_{\mathrm{g} 2}}
$$

where $T_{\mathrm{g}}$ is the glass transition temperature $\left(T_{\mathrm{g}}\right)$ of the block copolymer, $T_{\mathrm{g} 1}, T_{\mathrm{g} 2}$ and $w_{1}, w_{2}$ are $T_{\mathrm{g}}$ 's and weight fractions of the components 1 and 2, respectively.

Dynamic light scattering (DLS) (Malvern Zetasizer NanozS) was used to determine the hydrodynamic radius of the block copolymer in DMF with the addition of $0.01 \mathrm{M} \mathrm{LiBr}$. The concentration of the solutions studied was $100 \mathrm{mg} \mathrm{L}^{-1}$. 
Matrix-assisted laser desorption ionisation time-of-flight mass spectroscopy (MALDI-ToF MS) was conducted on a Bruker UltraFlex MALDI-ToF MS with a Scout-MTP Ion Source (Bruker Daltonics) equipped with a $\mathrm{N}_{2}$-laser (337 $\mathrm{nm}$ ), a gridless ion source, and a reflector. All spectra were acquired by a reflectorpositive method with an acceleration of $25 \mathrm{kV}$ and a reflector voltage of $26.3 \mathrm{kV}$. The laser intensity was set to the lowest value possible to acquire high-resolution spectra. The instrument was calibrated with SpheriCal ${ }^{\mathrm{TM}}$ calibrants kindly supplied by Polymer Factory Sweden AB. THF solutions of 2,5-dihydroxybenzoic acid (DHB) and trans-2-[3-(4-tert-butylphenyl)-2-methyl2-propenylidene]malononitrile (DCTB) were prepared $(10 \mathrm{mg}$ $\mathrm{mL}^{-1}$ ) and used as matrices. The solution of DCTB was doped with sodium chloride. The dried-droplet sample-preparation technique, adapted from Cordeiro et al. ${ }^{51}$ was used to obtain a $1: 1$ ratio (sample/matrix). $1 \mu \mathrm{L}$ of each sample, PDMAEMA or PCL, was directly applied on the MALDI plate, followed by the addition of $1 \mu \mathrm{L}$ of matrix solution, DHB for PDMAEMA and DCTB for PCL, and the sample was allowed to dry at room temperature to yield matrix crystallisation. The obtained spectra were analysed with FlexAnalysis Bruker Daltonics version 2.2.

\section{Synthesis}

All round bottom flasks and Schlenk tubes used in the reactions were equipped with stirring bars and closed with rubber septa, followed by drying with a heat gun - twice while evacuating and once under argon flow prior to use.

\section{ROP of $\varepsilon-C L$}

All glass equipment was dried overnight prior to use in an oven at $150{ }^{\circ} \mathrm{C}$ in addition to the regular drying procedure. $\mathrm{Sn}(\mathrm{Oct})_{2}$ (250 $\mathrm{mg}, 0.63 \mathrm{mmol}$ ) was introduced into a two-necked flask and dissolved in THF (3.0 mL) under stirring for $30 \mathrm{~min}$. HEBI $(0.29 \mathrm{~g}, 1.5 \mathrm{mmol})$ was dissolved in THF $(1.0 \mathrm{~mL})$ in a glass vial. $\varepsilon$-CL (17 mL, $0.15 \mathrm{~mol})$, the solution of HEBI and the solution of $\mathrm{Sn}(\mathrm{Oct})_{2}$ were injected into a Schlenk tube under a flow of argon, and stirred for $30 \mathrm{~min}$ at room temperature. The solution went from opaque to clear. The tube was then immersed in an oil bath preheated to $62{ }^{\circ} \mathrm{C}$ and the evolution of molecular weight was monitored by SEC in THF by withdrawing samples from the reaction mixture under argon flow. After $6 \mathrm{~h}$ the reaction mixture was allowed to cool down to ambient temperature, exposed to air, dissolved in THF and precipitated in a 10 -fold excess of cold $\mathrm{MeOH}\left(-20^{\circ} \mathrm{C}\right)$. The polymer was recovered via filtration and dried under reduced pressure at room temperature for $24 \mathrm{~h}$. Yield: $6.0 \mathrm{~g}$, 35\%, calculations based on $100 \%$ conversion. The product was denoted $\mathrm{Br}-\mathrm{PCL}-\mathrm{OH}$ and characterised by SEC and NMR analysis. ${ }^{1} \mathrm{H}$ NMR (400 $\left.\mathrm{MHz} ; \mathrm{CDCl}_{3}\right) \delta$ (ppm): 4.22-4.35 (4H, m, $\left.\mathrm{BrC}\left(\mathrm{CH}_{3}\right)_{2} \mathrm{C}(\mathrm{O}) \mathrm{OCH}_{2} \mathrm{CH}_{2} \mathrm{OC}(\mathrm{O})\left(\mathrm{CH}_{2}\right)_{5}\right)$, $4.00\left(2 \mathrm{H}, \mathrm{t}, J=5,-\left(\mathrm{CH}_{2}\right)_{4} \mathrm{CH}_{2} \mathrm{OC}(\mathrm{O})-\right), 3.58(2 \mathrm{H}, \mathrm{t}, J=6.3$, $\left.-\left(\mathrm{CH}_{2}\right)_{4} \mathrm{CH}_{2} \mathrm{OH}\right), 2.25\left(2 \mathrm{H}, \mathrm{t}, J=6.3,-\mathrm{OC}(\mathrm{O}) \mathrm{CH}_{2}\left(\mathrm{CH}_{2}\right)_{4}-\right), 1.87(6 \mathrm{H}$, s, $\left.\mathrm{Br}\left(\mathrm{C}\left(\mathrm{CH}_{3}\right)_{2} \mathrm{C}(\mathrm{O}) \mathrm{O}-\right)\right), 1.59\left(4 \mathrm{H}, \mathrm{m},-\mathrm{OC}(\mathrm{O}) \mathrm{CH}_{2} \mathrm{CH}_{2} \mathrm{CH}_{2} \mathrm{CH}_{2} \mathrm{CH}_{2}-\right)$, $1.32\left(2 \mathrm{H}, \mathrm{m},-\mathrm{OC}(\mathrm{O}) \mathrm{CH}_{2} \mathrm{CH}_{2} \mathrm{CH}_{2} \mathrm{CH}_{2} \mathrm{CH}_{2}\right)$.

\section{End-group conversion of Br-PCL-OH}

DMAP (11 mg, $0.086 \mathrm{mmol}$ ) and TEA (11 mg, $1.0 \mathrm{mmol}$ ) were added to a two-necked round-bottomed flask, and dissolved in THF $(5.0 \mathrm{~mL})$ at room temperature for 10 minutes. The flask was then placed in an ice bath followed by slow addition of BiB (89 $\mathrm{mg}, 0.39 \mathrm{mmol}$ ), upon which the mixture went from transparent to white. After an additional 10 minutes, the solution of Br-PCL$\mathrm{OH}$ (50 mg, $0.086 \mathrm{mmol})$ dissolved in THF $(5.0 \mathrm{~mL})$, was added drop-wise to the flask and the reaction was allowed to proceed overnight. The reaction mixture was precipitated twice in a 10fold excess of cold $\mathrm{MeOH}\left(-20{ }^{\circ} \mathrm{C}\right)$ and recovered via filtration, followed by drying at reduced pressure at room temperature for 24 h. Yield: $0.35 \mathrm{mg}, 68 \%$, calculations based on $100 \%$ conversion. The product was denoted $B r-P C L-B r, \mathbf{B}$, and characterised by NMR, SEC, MALDI-ToF and DSC analysis. ${ }^{1} \mathrm{H}$ NMR $\left(400 \mathrm{MHz} ; \mathrm{CDCl}_{3}\right) \delta(\mathrm{ppm}): 4.22-4.35\left(4 \mathrm{H}, \mathrm{m}, \mathrm{BrC}\left(\mathrm{CH}_{3}\right)_{2} \mathrm{C}(\mathrm{O})\right.$ $\left.\mathrm{OCH}_{2} \mathrm{CH}_{2} \mathrm{OC}(\mathrm{O})\left(\mathrm{CH}_{2}\right)_{5} \mathrm{O}(\mathrm{O}) \mathrm{C}\left(\mathrm{CH}_{3}\right)_{2} \mathrm{CBr}\right), 4.00(2 \mathrm{H}, \mathrm{t}, J=5$, $\left.-\left(\mathrm{CH}_{2}\right)_{4} \mathrm{CH}_{2} \mathrm{OC}(\mathrm{O})-\right), 2.25\left(2 \mathrm{H}, \mathrm{t}, J=6.3,-\mathrm{OC}(\mathrm{O}) \mathrm{CH}_{2}\left(\mathrm{CH}_{2}\right)_{4}{ }^{-}\right)$, $1.87\left(6 \mathrm{H}, \quad \mathrm{s}, \quad \mathrm{Br}\left(\mathrm{C}\left(\mathrm{CH}_{3}\right)_{2} \mathrm{C}(\mathrm{O}) \mathrm{O}-\right)\right), \quad 1.59 \quad(4 \mathrm{H}, \quad \mathrm{m}, \quad-\mathrm{OC}(\mathrm{O})$ $\left.\mathrm{CH}_{2} \mathrm{CH}_{2} \mathrm{CH}_{2} \mathrm{CH}_{2} \mathrm{CH}_{2}-\right), 1.32\left(2 \mathrm{H}, \mathrm{m},-\mathrm{OC}(\mathrm{O}) \mathrm{CH}_{2} \mathrm{CH}_{2} \mathrm{CH}_{2} \mathrm{CH}_{2} \mathrm{CH}_{2}\right.$ ).

\section{ATRP of DMAEMA from Br-PCL-Br}

The difunctional macroinitiator Br-PCL-Br $(40 \mathrm{mg}, 8.0 \mu \mathrm{mol})$ was dissolved in toluene $(0.20 \mathrm{~mL})$. Into a Schlenk tube, charged with $\mathrm{Cu}(\mathrm{I}) \mathrm{Br}(3.8 \mathrm{mg}, 26 \mu \mathrm{mol})$, the macroinitiator solution and DMAEMA $(0.19 \mathrm{~g}, 1.2 \mathrm{mmol})$ were added followed by attachment of a septum. Two freeze-pump-thaw cycles were conducted, followed by the addition of HMTETA (23 mg, 0.10 $\mathrm{mmol}$ ), and two more freeze-pump-thaw cycles were performed. The tube was immersed in an oil bath preheated to $70{ }^{\circ} \mathrm{C}$, and the reaction was allowed to proceed for $1 \mathrm{~h}$. Once the reaction had reached completion, the reaction mixture was allowed to cool down to ambient temperature under exposure to air, with subsequent addition of THF to dissolve the solid crude polymer. The polymer was precipitated into a 10-fold excess of cold heptane $\left(-78{ }^{\circ} \mathrm{C}\right)$. The heptane was decanted; the polymer was dissolved in THF, transferred to a vial and concentrated under reduced pressure. It was then dried under reduced pressure at room temperature for $24 \mathrm{~h}$. Yield: $0.20 \mathrm{~g}, 87 \%$, calculations based on $100 \%$ conversion. The final product was denoted PDMAEMA- $b$-PCL- $b$-PDMAEMA, ABA, and characterised by NMR, SEC, DSC and DLS analysis. ${ }^{1} \mathrm{H}$ NMR $\left(400 \mathrm{MHz} ; \mathrm{CDCl}_{3}\right) \delta$ (ppm): (PCL block) $4.00\left(2 \mathrm{H}, \mathrm{m},-\left(\mathrm{CH}_{2}\right)_{4} \mathrm{CH}_{2} \mathrm{OC}(\mathrm{O})-\right), 2.25(2 \mathrm{H}, \mathrm{m}$, $\left.-\mathrm{OC}(\mathrm{O}) \mathrm{CH}_{2}\left(\mathrm{CH}_{2}\right)_{4}{ }^{-}\right), 1.59\left(4 \mathrm{H}, \mathrm{m},-\mathrm{OC}(\mathrm{O}) \mathrm{CH}_{2} \mathrm{CH}_{2} \mathrm{CH}_{2} \mathrm{CH}_{2} \mathrm{CH}_{2}-\right)$, 1.32 (2H, m, -OC(O) $\mathrm{CH}_{2} \mathrm{CH}_{2} \mathrm{CH}_{2} \mathrm{CH}_{2} \mathrm{CH}_{2}$ ), (PDMAEMA blocks) $4.00\left(2 \mathrm{H}, \mathrm{m},-\mathrm{CH}_{2} \mathrm{OC}(\mathrm{O}) \mathrm{C}-\right), 2.51\left(2 \mathrm{H}, \mathrm{m},-\mathrm{CH}_{2} \mathrm{~N}_{(}\left(\mathrm{CH}_{3}\right)_{2}\right), 2.23$ $\left(6 \mathrm{H}, \mathrm{m},-(\mathrm{O}) \mathrm{COCCH}_{2} \mathrm{CH}_{2} \mathrm{~N}\left(\mathrm{CH}_{3}\right)_{2}\right), 1.86-1.77\left(2 \mathrm{H}, \mathrm{s},-\mathrm{CH}_{2} \mathrm{C}(\mathrm{C}(\mathrm{O})\right.$ $\left.\left.\mathrm{CH}_{3}-\right)\right)$, $1.00-0.85\left(3 \mathrm{H}, \mathrm{s},-\mathrm{CH}_{2} \mathrm{C}\left(\mathrm{C}(\mathrm{O}) \mathrm{CH}_{3}-\right)\right)$.

\section{ATRP of DMAEMA}

To a $50 \mathrm{~mL}$ round-bottomed flask, DMAEMA (20 g, $0.13 \mathrm{~mol}$ ), acetone ( $20 \mathrm{~g})$, HEBI $(0.36 \mathrm{~g}, 1.7 \mathrm{mmol})$ and HMTETA $(0.78 \mathrm{~g}, 3.4$ mmol) were added. The flask was thereafter closed with a rubber septum and evacuated and back-filled with argon. Thereafter, the septum was carefully removed and $\mathrm{Cu}(\mathrm{I}) \mathrm{Cl}(0.17$ 
$\mathrm{mg}, 1.7 \mathrm{mmol}$ ) was added, after which the septum was reattached and two more vacuum/argon cycles were performed. The flask was immersed in an oil bath preheated to $50{ }^{\circ} \mathrm{C}$ and the reaction was allowed to proceed for 45 minutes. After that time, the flask was removed from the oil bath, the septum was carefully removed, $\mathrm{Cu}(\mathrm{II}) \mathrm{Br}_{2}(0.10 \mathrm{mg}, 0.45 \mathrm{mmol})$ was added, the septum was reattached, and the reaction mixture was left stirring at ambient temperature under argon flow for 20 minutes. The septum was removed and THF was added to dissolve the polymer formed. The polymer solution was passed through an activated, neutral $\mathrm{Al}_{2} \mathrm{O}_{3}$ column to remove the copper salt and was thereafter precipitated in a 10-fold excess of cold heptane $\left(-78{ }^{\circ} \mathrm{C}\right)$. The heptane was decanted, the polymer dissolved in THF, transferred to a vial and concentrated under reduced pressure. It was then dried under reduced pressure at room temperature for $24 \mathrm{~h}$. Yield: $7.4 \mathrm{~g}, 36 \%$, calculations based on $100 \%$ conversion. The final product was denoted $\mathrm{HO}$ PDMAEMA-Br, A-1, and characterised by NMR, SEC, FT-IR, DSC and MALDI-ToF analysis. ${ }^{1} \mathrm{H}$ NMR (400 $\left.\mathrm{MHz} ; \mathrm{CDCl}_{3}\right) \delta(\mathrm{ppm})$ : $4.00\left(2 \mathrm{H}, \mathrm{m},-\mathrm{CH}_{2} \mathrm{OC}(\mathrm{O}) \mathrm{C}-\right), 2.51\left(2 \mathrm{H}, \mathrm{m},-\mathrm{CH}_{2} \mathrm{~N}\left(\mathrm{CH}_{3}\right)_{2}\right), 2.23$ $\left(6 \mathrm{H}, \mathrm{s},-(\mathrm{O}) \mathrm{COCCH}_{2} \mathrm{CH}_{2} \mathrm{~N}\left(\mathrm{CH}_{3}\right)_{2}\right), 1.90\left(3 \mathrm{H}, \mathrm{s},-\mathrm{CH}_{2} \mathrm{C}(\mathrm{C}(\mathrm{O})\right.$ $\left.\left.\mathrm{CH}_{3} \mathrm{Br}\right)\right), 1.86-1.77\left(2 \mathrm{H}, \mathrm{s},-\mathrm{CH}_{2} \mathrm{C}\left(\mathrm{C}(\mathrm{O}) \mathrm{CH}_{3}-\right)\right), 1.00-0.85(3 \mathrm{H}, \mathrm{s}$, $\left.-\mathrm{CH}_{2} \mathrm{C}\left(\mathrm{C}(\mathrm{O}) \mathrm{CH}_{3}-\right)\right)$.

\section{End-group conversion of HO-PDMAEMA-Br}

A dried two-necked round-bottomed flask was charged with $\mathrm{HO}-$ PDMAEMA-Br (5.5 g, $1.6 \mathrm{mmol})$ and DMF $(20 \mathrm{~mL})$. After the polymer was dissolved, $\mathrm{NaN}_{3}(1.1 \mathrm{~g}, 16 \mathrm{mmol})$ was added and the flask was sealed with a rubber septum. The flask was immersed in an oil bath preheated to $80{ }^{\circ} \mathrm{C}$ and the reaction was left to proceed for $24 \mathrm{~h}$. After the reaction was completed, the reaction mixture was allowed to cool down to ambient temperature. A 10fold excess of deionised water was heated to $70{ }^{\circ} \mathrm{C}$, and the reaction mixture was added drop-wise to the water and stirred for $10 \mathrm{~min}$, upon which the product became insoluble and stuck to the walls. The water was decanted off, the product dissolved in THF, transferred to a vial and concentrated under reduced pressure. It was dried under reduced pressure at room temperature for $24 \mathrm{~h}$. Yield: $3.1 \mathrm{~g}, 55 \%$, calculations based on $100 \%$ conversion. The final product was denoted $H O-P D M A E M A-N_{3}, \mathbf{A}-$ 2, and characterised by NMR, FT-IR and SEC analysis. ${ }^{1} \mathrm{H}$ NMR $\left(400 \mathrm{MHz} ; \mathrm{CDCl}_{3}\right) \delta(\mathrm{ppm}): 4.00\left(2 \mathrm{H}, \mathrm{m},-\mathrm{CH}_{2} \mathrm{OC}(\mathrm{O}) \mathrm{C}-\right), 2.51(2 \mathrm{H}$, $\left.\mathrm{m},-\mathrm{CH}_{2} \mathrm{~N}\left(\mathrm{CH}_{3}\right)_{2}\right), 2.23\left(6 \mathrm{H}, \mathrm{s},-(\mathrm{O}) \mathrm{COCCH}_{2} \mathrm{CH}_{2} \mathrm{~N}\left(\mathrm{CH}_{3}\right)_{2}\right), 1.86-$ $1.77\left(2 \mathrm{H}, \mathrm{s},-\mathrm{CH}_{2} \mathrm{C}\left(\mathrm{C}(\mathrm{O}) \mathrm{CH}_{3}-\right)\right), 1.38\left(3 \mathrm{H}, \mathrm{s},-\mathrm{CH}_{2} \mathrm{C}\left(\mathrm{C}(\mathrm{O}) \mathrm{CH}_{3} \mathrm{~N}_{3}\right)\right)$, 1.00-0.85 (3H, s, $\left.-\mathrm{CH}_{2} \mathrm{C}\left(\mathrm{C}(\mathrm{O}) \mathrm{CH}_{3}-\right)\right)$.

\section{End-group conversion of HO-PDMAEMA-N $\mathbf{N}_{3}$}

A Schlenk tube was charged with HO-PDMAEMA-N ${ }_{3}(1.0 \mathrm{~g}, 0.29$ $\mathrm{mmol}$ ), propargyl alcohol (22 $\mathrm{mg}, 0.37 \mathrm{mmol}), \mathrm{Cu}(\mathrm{I}) \mathrm{Br}(82 \mathrm{mg}$, $0.57 \mathrm{mmol}$ ) and DMF $(12 \mathrm{~mL})$, and sealed with a septum. All reactants were allowed to dissolve under stirring. Three freezepump-thaw cycles were performed. PMDETA (99 mg, 0.57 $\mathrm{mmol}$ ) was degassed through three cycles of 5 minutes alternating evacuation and back-filling of argon, and it was then added to the tube. The tube was placed in an oil bath set to $25^{\circ} \mathrm{C}$, and the reaction was allowed to proceed for $24 \mathrm{~h}$. In the next step, the septum was removed and THF was added. The polymer solution was passed through an activated, neutral $\mathrm{Al}_{2} \mathrm{O}_{3}$ column to remove the copper salt and was thereafter concentrated under reduced pressure at elevated temperature to remove the DMF. The polymer was dissolved in THF and precipitated twice in a 10fold excess of cold heptane $\left(-78^{\circ} \mathrm{C}\right)$. The heptane was decanted, the polymer dissolved in THF, transferred to a vial and concentrated under reduced pressure. It was then dried under reduced pressure at room temperature for $24 \mathrm{~h}$ Yield: $0.49 \mathrm{~g}$, $48 \%$, calculations based on $100 \%$ conversion. The final product was denoted HO-PDMAEMA-OH, A-3, and characterised by NMR, FT-IR and SEC analyses. The product is ${ }^{1} \mathrm{H}$ NMR $(400 \mathrm{MHz}$; $\left.\mathrm{CDCl}_{3}\right) \delta(\mathrm{ppm}): 7.70(1 \mathrm{H}, \mathrm{s},-\mathrm{CNCHC}-), 4.71(2 \mathrm{H}, \mathrm{m}$, $\left.\mathrm{HOCH}_{2} \mathrm{CCHNC}-\right), 4.00\left(2 \mathrm{H}, \mathrm{m},-\mathrm{CH}_{2} \mathrm{OC}(\mathrm{O}) \mathrm{C}-\right), 2.51(2 \mathrm{H}, \mathrm{m}$, $\left.-\mathrm{CH}_{2} \mathrm{~N}\left(\mathrm{CH}_{3}\right)_{2}\right), 2.23\left(6 \mathrm{H}, \mathrm{s},-(\mathrm{O}) \mathrm{COCCH}_{2} \mathrm{CH}_{2} \mathrm{~N}\left(\mathrm{CH}_{3}\right)_{2}\right), 1.86-1.77$ $\left(2 \mathrm{H}, \mathrm{s},-\mathrm{CH}_{2} \mathrm{C}\left(\mathrm{C}(\mathrm{O}) \mathrm{CH}_{3}-\right)\right), 1.38\left(3 \mathrm{H}, \mathrm{s},-\mathrm{CH}_{2} \mathrm{C}\left(\mathrm{C}(\mathrm{O}) \mathrm{CH}_{3} \mathrm{~N}_{3} \mathrm{C}-\right)\right)$, 1.00-0.85 (3H, s, $\left.-\mathrm{CH}_{2} \mathrm{C}\left(\mathrm{C}(\mathrm{O}) \mathrm{CH}_{3}^{-}\right)\right)$.

\section{ROP of $\varepsilon$-CL from HO-PDMAEMA-OH}

All glass equipment was dried prior to use in an oven at $150{ }^{\circ} \mathrm{C}$. Into a two-necked round-bottomed flask $\mathrm{Sn}(\mathrm{Oct})_{2}$ (31 $\mathrm{mg}$, $80 \mu \mathrm{mol})$ was introduced and dissolved in toluene $(2.0 \mathrm{~mL})$ under stirring for $30 \mathrm{~min}$. HO-PDMAEMA-OH $(0.30 \mathrm{~g}, 90 \mu \mathrm{mol})$ was dissolved in toluene $(1.0 \mathrm{~mL})$ in a glass vial. A Schlenk tube was charged with $\varepsilon$-CL $(2.1 \mathrm{~mL}, 19 \mathrm{mmol})$, the solution of HOPDMAEMA-OH and the solution of $\mathrm{Sn}(\mathrm{Oct})_{2}$, and the reaction mixture was stirred for $10 \mathrm{~min}$ at room temperature under a flow of argon. The tube was then immersed in an oil bath preheated to $62{ }^{\circ} \mathrm{C}$. After $69 \mathrm{~h}$, the reaction mixture was allowed to cool down to ambient temperature, exposed to air, dissolved in THF and precipitated in a 10 -fold excess of cold $\mathrm{MeOH}\left(-20^{\circ} \mathrm{C}\right)$. The polymer was recovered via filtration and then dried under reduced pressure at room temperature for $24 \mathrm{~h}$. Yield: $1.0 \mathrm{~g}$, $43 \%$, calculations based on $100 \%$ conversion. The final product was denoted $P C L-b-P D M A E M A-b-P C L, \mathbf{B A B}$, and characterised by NMR and SEC analysis. ${ }^{1} \mathrm{H}$ NMR $\left(400 \mathrm{MHz} ; \mathrm{CDCl}_{3}\right) \delta(\mathrm{ppm}):(\mathrm{PCL}$ blocks) 4.00 (2H, m, - $\left.\left(\mathrm{CH}_{2}\right)_{4} \mathrm{CH}_{2} \mathrm{OC}(\mathrm{O})-\right), 2.25(2 \mathrm{H}, \mathrm{m},-\mathrm{OC}(\mathrm{O})-$ $\left.\mathrm{CH}_{2}\left(\mathrm{CH}_{2}\right)_{4}^{-}\right), 1.59\left(4 \mathrm{H}, \mathrm{m},-\mathrm{OC}(\mathrm{O}) \mathrm{CH}_{2} \mathrm{CH}_{2} \mathrm{CH}_{2} \mathrm{CH}_{2} \mathrm{CH}_{2}^{-}\right), 1.32$ $\left(2 \mathrm{H}, \mathrm{m},-\mathrm{OC}(\mathrm{O}) \mathrm{CH}_{2} \mathrm{CH}_{2} \mathrm{CH}_{2} \mathrm{CH}_{2} \mathrm{CH}_{2}\right.$ ), (PDMAEMA block) 4.00 $\left(2 \mathrm{H}, \mathrm{m},-\mathrm{CH}_{2} \mathrm{OC}(\mathrm{O}) \mathrm{C}-\right), 2.51\left(2 \mathrm{H}, \mathrm{m},-\mathrm{CH}_{2} \mathrm{~N}\left(\mathrm{CH}_{3}\right)_{2}\right), 2.23(6 \mathrm{H}, \mathrm{m}$, $\left.-(\mathrm{O}) \mathrm{COCCH}_{2} \mathrm{CH}_{2} \mathrm{~N}\left(\mathrm{CH}_{3}\right)_{2}\right), 1.86-1.77\left(2 \mathrm{H}, \mathrm{s},-\mathrm{CH}_{2} \mathrm{C}\left(\mathrm{C}(\mathrm{O}) \mathrm{CH}_{3}-\right)\right)$, 1.00-0.85 (3H, s, $\left.-\mathrm{CH}_{2} \mathrm{C}\left(\mathrm{C}(\mathrm{O}) \mathrm{CH}_{3}^{-}\right)\right)$.

\section{Purification attempts for the triblock PCL- $b$-PDMAEMA- $b$-PCL}

The product was dissolved in THF and precipitation was attempted in a 10 -fold excess of heptane $\left(-78^{\circ} \mathrm{C}\right)$. The product did not precipitate. The heptane was therefore concentrated and the polymer was dissolved in THF, followed by alternating ultrasonication for 5 minutes and precipitation of small amounts of polymer solution in a 10 -fold excess of $\mathrm{MeOH}\left(-78^{\circ} \mathrm{C}\right)$. The product was dissolved in DMF and precipitated in a 10 -fold excess of ether $\left(-78{ }^{\circ} \mathrm{C}\right)$. The product was dissolved in THF and fractionated precipitation was performed by slowly adding $\mathrm{MeOH}$ (RT) drop-wise. The product was subjected to separation attempts through Sephadex columns, both with THF and DMF as mobile phase followed by precipitation in a 10-fold excess of 
$\mathrm{MeOH}\left(-78{ }^{\circ} \mathrm{C}\right)$ and a 10 -fold excess of ether $\left(-78^{\circ} \mathrm{C}\right)$, respectively. Finally, attempts to separate the product was performed through ultrafiltration (MWCO $10000 \mathrm{~g} \mathrm{~mol}^{-1}$ ) in DMF and precipitation in a 10 -fold excess of ether $\left(-78{ }^{\circ} \mathrm{C}\right)$. The fractions were characterised by NMR, SEC, DLS and DSC analysis.

\section{Conversion of PDMAEMA into PMMA for SEC analysis}

The procedure for converting PDMAEMA into poly(methyl methacrylate) (PMMA) was adopted from Plamper et al. ${ }^{52}$ and was divided into three parts: quaternisation, alkaline hydrolysis and alkylation.

PDMAEMA (1.0 g, $6.4 \mathrm{mmol})$ was dissolved in THF $(18 \mathrm{~mL})$ in a $50 \mathrm{~mL}$ round-bottomed flask. MeI $(1.1 \mathrm{~g}, 7.6 \mathrm{mmol})$ was dissolved in THF (5.0 mL), and added drop-wise to the PDMAEMA solution, the flask was sealed with a septum and the mixture left to stir overnight. The polymer solution was precipitated in a 10fold excess of cold heptane $\left(-78{ }^{\circ} \mathrm{C}\right)$, filtered and dried under reduced pressure at room temperature for $24 \mathrm{~h}$. Yield: $0.40 \mathrm{~g}$, $37 \%$, calculations based on $100 \%$ conversion. The final product was denoted $q P D M A E M A$, and characterised by ${ }^{1} \mathrm{H}-\mathrm{NMR}$ analysis. ${ }^{1} \mathrm{H}$ NMR (400 MHz; $\left.\mathrm{D}_{2} \mathrm{O}\right) \delta(\mathrm{ppm}): 3.92(2 \mathrm{H}, \mathrm{m}$, $\left.-\left(\mathrm{CH}_{3}\right)_{3} \mathrm{NCH}_{2} \mathrm{CH}_{2} \mathrm{OC}(\mathrm{O}) \mathrm{C}-\right)$, $3.35\left(11 \mathrm{H}, \mathrm{m},-\mathrm{CH}_{2} \mathrm{~N}\left(\mathrm{CH}_{3}\right)_{3}\right), 2.10$ $\left(2 \mathrm{H}, \mathrm{s},-\mathrm{CH}_{2} \mathrm{C}\left(\mathrm{C}(\mathrm{O}) \mathrm{CH}_{3}-\right)\right)$, 1.21-1.09 (3H, s, $\left.-\mathrm{CH}_{2} \mathrm{C}\left(\mathrm{C}(\mathrm{O}) \mathrm{CH}_{3}-\right)\right)$.

qPDMAEMA ( $0.40 \mathrm{~g})$ was dissolved and stirred in a concentrated aqueous $\mathrm{NaOH}$ solution $(8.0 \mathrm{~mL})$ for 5 days at $90{ }^{\circ} \mathrm{C}$. A dark precipitate was formed that was filtered off through a nylon filter. $\mathrm{HCl}$ was added drop-wise until the $\mathrm{pH}$ turned slightly acidic, determined with litmus paper, followed by freeze drying overnight to remove residual $\mathrm{HCl}$. The product, poly(methacrylic acid) (PMAA), was dissolved in deionised water (8.0 $\mathrm{mL}$ ) and subjected to aqueous dialysis (Millipore SpectraPore 7 MWCO 1000). To assure that the product was fully protonated, the steps from the addition of $\mathrm{HCl}$ to freeze drying were repeated. Yield: $85 \mathrm{mg}, 21 \%$, calculations based on $100 \%$ conversion. ${ }^{1} \mathrm{H}-\mathrm{NMR}$ analysis in $\mathrm{D}_{2} \mathrm{O}$ was conducted to assess the outcome of the hydrolysis. ${ }^{1} \mathrm{H}$ NMR $\left(400 \mathrm{MHz} ; \mathrm{D}_{2} \mathrm{O}\right) \delta(\mathrm{ppm})$ : $2.10\left(2 \mathrm{H}, \quad \mathrm{s}, \quad-\mathrm{CH}_{2} \mathrm{C}\left((\mathrm{C}(\mathrm{O}) \mathrm{OH}) \mathrm{CH}_{3}-\right)\right), \quad 1.21-1.09 \quad(3 \mathrm{H}, \quad \mathrm{s}$, $\left.-\mathrm{CH}_{2} \mathrm{C}\left((\mathrm{C}(\mathrm{O}) \mathrm{OH}) \mathrm{CH}_{3}\right)\right)$.

PMAA $(30 \mathrm{mg})$ was dissolved in deionised water $(0.40 \mathrm{~mL})$ and THF $(6.0 \mathrm{~mL})$. Trimethyldiazomethane solution was added drop-wise while stirring until the yellow colour formed was stable for more than 1 hour. Subsequent dialysis in THF (Millipore SpectraPore 7 MWCO 1000) was performed, and drying of the resulting PMMA, C, at reduced pressure for $24 \mathrm{~h}$. Yield: 10 $\mathrm{mg}, 24 \%$, calculations based on $100 \%$ conversion. The final product was characterized by ${ }^{1} \mathrm{H}$-NMR and SEC analysis. ${ }^{1} \mathrm{H}$ NMR (400 MHz; $\left.\mathrm{CDCl}_{3}\right) \delta(\mathrm{ppm}): 3.59\left(3 \mathrm{H}, \mathrm{s},-\mathrm{CH}_{2} \mathrm{C}\left(\mathrm{C}(\mathrm{O}) \mathrm{OCH}_{3}\right)\right.$ $\left.\mathrm{CH}_{3}{ }^{-}\right)$, 1.86-1.77 (2H, s, $\left.-\mathrm{CH}_{2} \mathrm{C}\left(\mathrm{C}(\mathrm{O}) \mathrm{OCH}_{3}\right) \mathrm{CH}_{3}-\right)$, 1.21-1.09 $\left(3 \mathrm{H}, \mathrm{s},-\mathrm{CH}_{2} \mathrm{C}\left(\mathrm{C}(\mathrm{O}) \mathrm{OCH}_{3}\right) \mathrm{CH}_{3}-\right)$.

\section{Results and discussion}

Scheme 1 depicts the synthesis of Br-PCL-Br, and the ABA-type triblock, PDMAEMA- $b$-PCL- $b$-PDMAEMA. In the first step, $\mathrm{Sn}(\mathrm{Oct})_{2}$-catalysed Ring-Opening Polymerisation (ROP) of $\varepsilon$-CL was initiated by the heterobifunctional HEBI, carrying a single
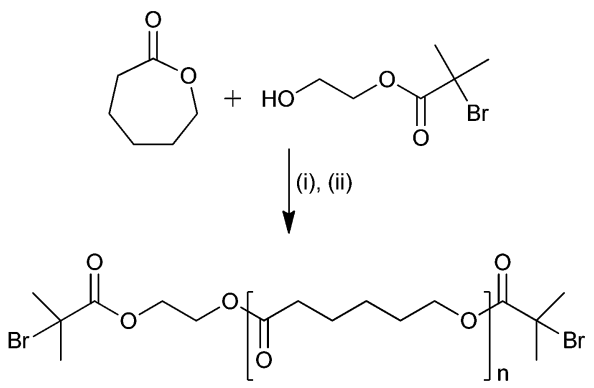

B

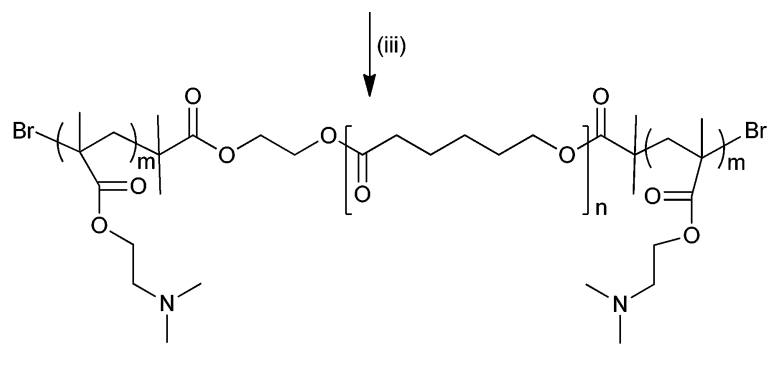

ABA

Scheme 1 Synthesis of the triblock PDMAEMA- $b-P C L-b$-PDMAEMA (ABA). Reagents and conditions: (i) $\varepsilon-\mathrm{CL}, \mathrm{Sn}(\mathrm{Oct})_{2}, \mathrm{THF}, 62^{\circ} \mathrm{C}$; (ii) $\mathrm{BiB}$, DMAP, TEA, THF, $25^{\circ} \mathrm{C}$; (iii) DMAEMA, Cu(I)Br, HMTETA, toluene, $70^{\circ} \mathrm{C}$.

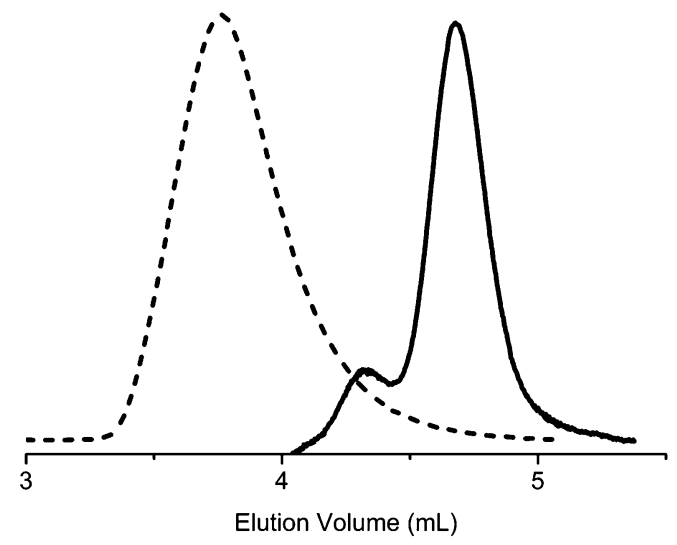

Fig. 1 SEC traces of $\mathrm{Br}-\mathrm{PCL}-\mathrm{Br}$ ( $\mathrm{B}$, solid line) and the triblock PDMAEMA- $b-P C L-b-P D M A E M A$ (ABA, dashed line), acquired in DMF + $0.01 \mathrm{M} \mathrm{LiBr}$.

Atom Transfer Radical Polymerisation (ATRP) initiating site and a hydroxyl-group. The polymerization resulted in a PCL-block with an ATRP-initiator at one chain-end and an $\mathrm{OH}$-functionality at the other. In order to perform ATRP of DMAEMA from both ends of this polymer, a second ATRP initiating site was introduced by the reaction of the $\omega$-hydroxyl function with $\mathrm{BiB}$, creating Br-PCL-Br, B. The SEC trace of $\mathbf{B}$ exhibited a small shoulder on the high molecular weight side (Fig. 1), which was originating from the original precursor (Br-PCL-OH). Therefore, it is hypothesised that this most likely is attributed to transesterification reactions taking place during the ROP and not during the end-group transformation. ${ }^{1} \mathrm{H}$ NMR experiment confirmed near to quantitative transformation of the hydroxylfunctional group into the ATRP initiator. 
Table 1 Molecular weights and $\emptyset_{M}$ of $\mathrm{HO}-\mathrm{PDMAEMA}-\mathrm{OH}(\mathrm{A}-3), \mathrm{Br}-$ $\mathrm{PCL}-\mathrm{Br}(\mathrm{B})$ and triblock copolymers determined by ${ }^{1} \mathrm{H}-\mathrm{NMR}, \mathrm{MALDI}-$ TOF and SEC

\begin{tabular}{llllll}
\hline Polymer & $M_{\text {Theo }}{ }^{a}[\mathrm{Da}]$ & $\bar{M}_{\mathrm{n}}{ }^{b}[\mathrm{Da}]$ & $\bar{M}_{\mathrm{n}}{ }^{c}[\mathrm{Da}]$ & $\bar{M}_{\mathrm{n}}{ }^{d}[\mathrm{Da}]$ & $D_{\mathrm{M}}$ \\
\hline B & 12400 & 6000 & 5300 & 11800 & 1.11 \\
ABA & 28600 & 24200 & - & 50000 & 1.24 \\
A-3 & 12000 & 3100 & 3100 & 8400 & 1.19 \\
BAB & 28100 & 41800 & - & 34800 & 1.19
\end{tabular}

${ }^{a}$ Based on $100 \%$ conversion. ${ }^{b}$ Determined by ${ }^{1} \mathrm{H}-\mathrm{NMR}$ in $\mathrm{CDCl}_{3}$. ${ }^{c}$ Highest intensity peak from MALDI-TOF. ${ }^{d}$ Determined from DMFSEC.

B was chain-extended with DMAEMA via Cu(I)Br/HMTETAmediated ATRP in toluene at $70{ }^{\circ} \mathrm{C}$ (Scheme 1) to yield polymer ABA. Excess of HMTETA was employed to overcome the undesirable ligation of the copper salts with the monomer. Fairly high macroinitiator efficiency was perceived as the SEC trace underwent a clear shift to a lower elution volume (Fig. 1). Despite a slight tailoring of ABA, which has been observed for homopolymerisation and chain extension of PDMAEMA previously, ${ }^{51} D_{M}$ of 1.24 confirmed good control over the reaction. The molecular weight characteristics of macroinitiators and block copolymers are summarised in Table 1 .

Successful formation of ABA was verified by ${ }^{1} \mathrm{H}$ NMR experiment (Fig. 2, top). Resonances originating from both PCL and PDMAEMA blocks were observed. The notations a and s, added to $f$ and $g$, designate whether the monomer sequence in the PDMAEMA backbone is atactic or syndiotactic, respectively. ${ }^{53}$

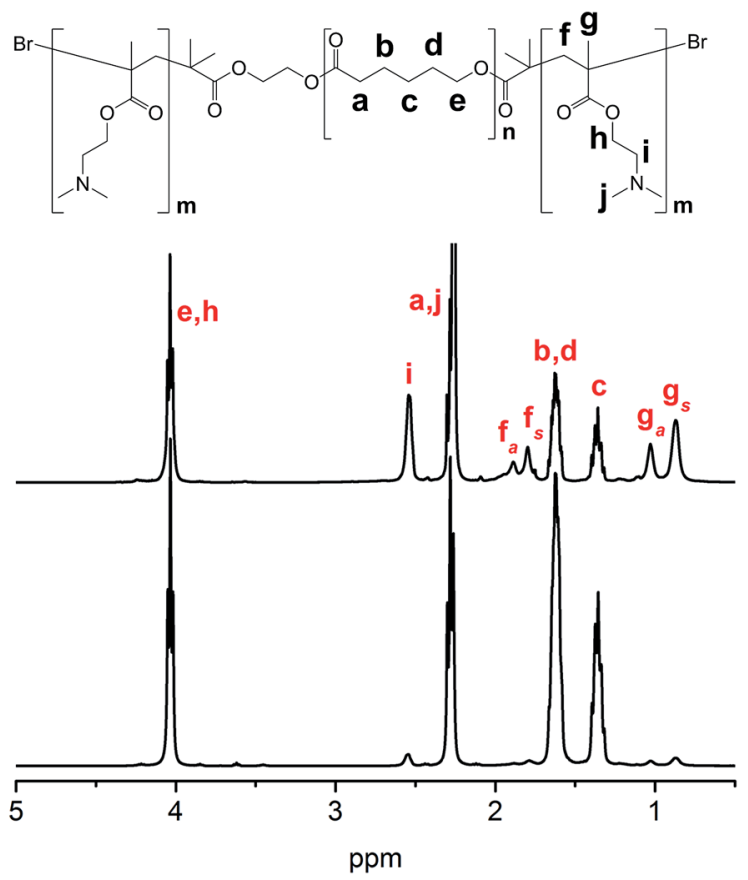

Fig. $2{ }^{1} \mathrm{H}-\mathrm{NMR}$ spectra of the two triblocks PDMAEMA- $b-\mathrm{PCL}-b-$ PDMAEMA (ABA, top) and PCL- $b$-PDMAEMA- $b$-PCL (BAB, bottom) in $\mathrm{CDCl}_{3}$. Notations $\mathrm{a}$ and $\mathrm{s}$ added to $\mathrm{f}$ and $\mathrm{g}$ refer to tacticity; atactic and syndiotactic, respectively.
The degree of polymerization (DP) of the PDMAEMA blocks was estimated to be 58 by comparing the integrals of the peaks $\mathrm{c}$ and i, which were ascribed to PCL and PDMAEMA, respectively.

Having obtained PDMAEMA- $b$-PCL- $b$-PDMAEMA triblock copolymer ABA (Scheme 1), the synthesis of PCL- $b$-PDMAEMA$b$-PCL (BAB) was carried out according to scheme 2. ATRP of DMAEMA was mediated by $\mathrm{Cu}(\mathrm{I}) \mathrm{Cl} / \mathrm{HMTETA}$ catalytic complex, and chlorine atoms at the "living" termini were exchanged by bromine atoms by addition of $\mathrm{Cu}(\mathrm{II}) \mathrm{Br}_{2}$ at the end of the reaction. Thus, heterobifunctional HO-PDMAEMA-Br A-1 (Scheme 2) with the DP $=20$ (estimated by NMR spectroscopy) and the $\emptyset_{\mathrm{M}}=1.25$ was obtained in a controlled manner. The second hydroxyl-functional group was introduced via the $\mathrm{Cu}(\mathrm{I})$-catalysed "click" reaction. Initially, nucleophilic substitution with $\mathrm{NaN}_{3}$ afforded HO-PDMAEMA-N 3 A-2 (Scheme 2). Then A-2 was reacted with propargyl alcohol (1.3 eq.) yielding HO-PDMAEMAOH, A-3 (Scheme 2). The end-group conversion from bromine to hydroxyl via azide was monitored and verified by NMR and FTIR spectroscopy.

The overlay of the ${ }^{1} \mathrm{H}$-NMR spectra of HO-PDMAEMA-Br A-1 (Scheme 2) and HO-PDMAEMA-N ${ }_{3}$ A-2 (Scheme 2) is depicted in Fig. 3. It is the subtle change - up field shift of the resonance signal assigned to the methyl group of the ultimate repeating unit (the shift of $\mathrm{d}^{\prime}$ to $\mathrm{d}^{\prime \prime}$ ) - that corroborates the success of the reaction. ${ }^{46}$ However, quantification of the extent of the reaction is made difficult by the overlapping resonance peaks. The ${ }^{1} \mathrm{H}$ NMR spectrum of the "click" reaction product, HO-PDMAEMA$\mathrm{OH}$ A-3, is shown in Fig. 4. Methylene groups a and $\mathrm{h}$ - adjacent to the $\alpha$ - and $\omega$-hydroxyl functions, respectively - can be identified. HSQC NMR experiment reveals that proton $h$ at $4.68 \mathrm{ppm}$ correlates with the carbon nucleus resonating at $55.86 \mathrm{ppm}$ (Fig. S1†); thus it can be unambiguously attributed to the methylene group between the triazole ring and the hydroxyl function. Furthermore, in Fig. 5 FT-IR spectra of the end-group conversion HO-PDMAEMA-Br (A-1) to HO-PDMAEMA-OH (A-3) via HO-PDMAEMA-N ${ }_{3}$ (A-2) (Scheme 2) show the appearance and disappearance of the azide group (around $2100 \mathrm{~cm}^{-1}$ ) ${ }^{54}$ in the sample, supporting the conclusion of a successful conversion from A-1 to A-3. No other peaks in Fig. 5 undergo any changes. A-3 was chain extended via ROP of $\varepsilon$-CL catalysed by $\mathrm{Sn}(\mathrm{Oct})_{2}$ in toluene (Scheme 2, BAB). With ${ }^{1} \mathrm{H}$-NMR experiment (Fig. 2, bottom) resonance signals originating from both PCL and PDMAEMA blocks were observed and the DP of the PCL blocks was estimated to be 335 by comparing the integrals of peaks $\mathrm{c}$ and $\mathrm{i}$, which were ascribed to PCL and PDMAEMA, respectively. This DP is corresponding to a total molecular weight of 41800 , which is higher than the theoretical molecular weight, a difference that could be ascribed to the difference in solubility of PCL and PDMAEMA in $\mathrm{CDCl}_{3}$, hence PDMAEMA is shielded and less pronounced in NMR.

A clear shift of the elution volume in the SEC trace (Fig. 6) was detected, indicating a good macroinitiator efficiency, i.e., initiation occurred in both ends followed by efficient propagation of $\varepsilon$-CL. However, the trace was bimodal, giving the impression that the final product contained a mixture of di- and triblock copolymers. Therefore, several attempts were performed to purify the product and separate potential diblocks 
<smiles>C=C(C)C(=O)OCCN(C)C</smiles>

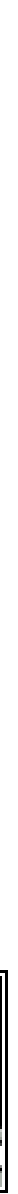

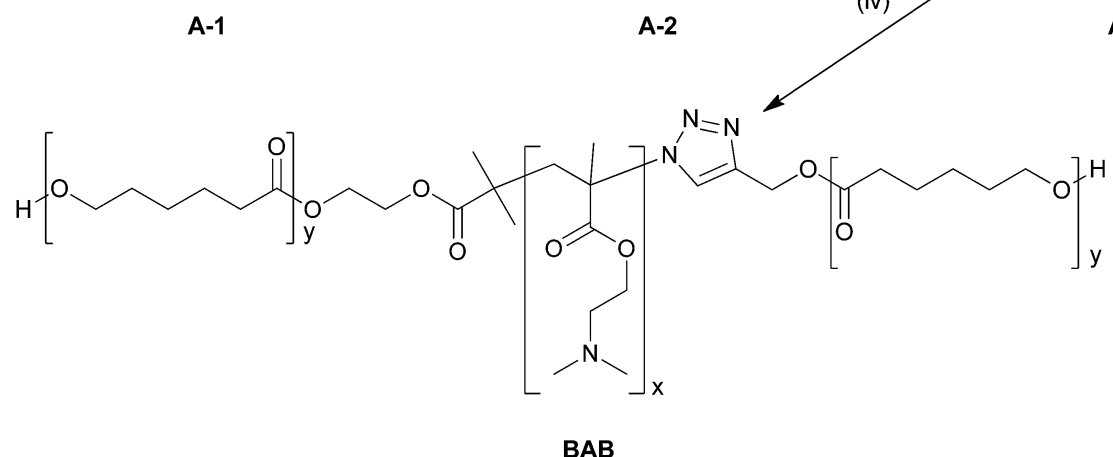

Scheme 2 Synthesis of the triblock PCL-b-PDMAEMA- $b-P C L$. Reagents and conditions: (i) DMAEMA, $\mathrm{Cu}\left(\right.$ () $\mathrm{Cl}, \mathrm{HMTETA}$, acetone, $50{ }^{\circ} \mathrm{C}$; (ii) $\mathrm{NaN}$, DMF, $80{ }^{\circ} \mathrm{C}$; (iii) propargyl alcohol, $\mathrm{Cu}\left(\right.$ () Br, PMDETA, DMF, $25^{\circ} \mathrm{C}$; (iv) $\varepsilon$ - $\mathrm{CL}$, Sn $(\mathrm{Oct})_{2}$, toluene, $62{ }^{\circ} \mathrm{C}$.

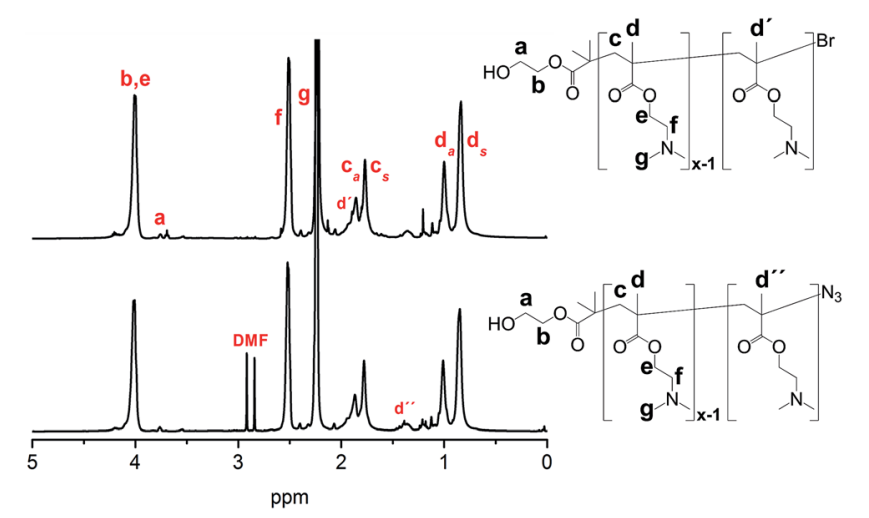

Fig. $3{ }^{1} \mathrm{H}-\mathrm{NMR}$ spectra: conversion from HO-PDMAEMA-Br (top spectrum) to $\mathrm{HO}-\mathrm{PDMAEMA}-\mathrm{N}_{3}$ (bottom spectrum) in $\mathrm{CDCl}_{3}$.
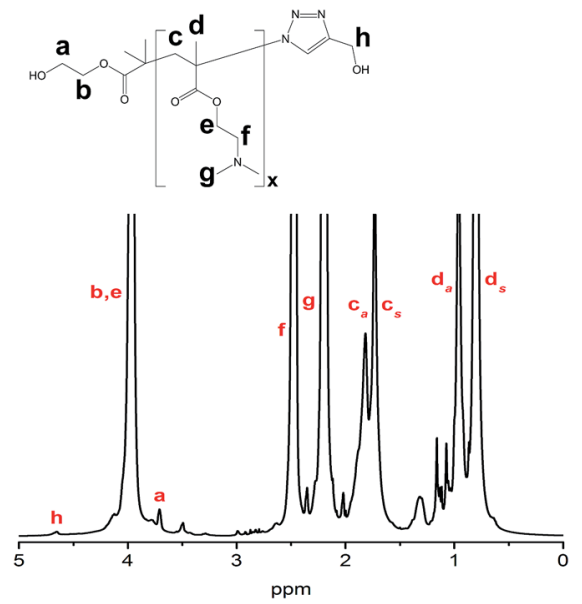

Fig. $4{ }^{1} \mathrm{H}-\mathrm{NMR}$ spectrum of $\mathrm{HO}-\mathrm{PDMAEMA}-\mathrm{OH}(\mathrm{A}-3)$ in $\mathrm{CDCl}_{3}$.

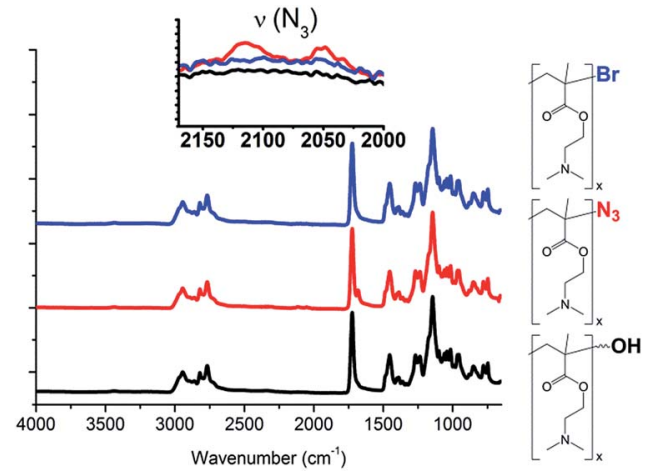

Fig. 5 FT-IR spectra of products from end-group conversion experiments from bromide to azide and subsequent "click" reaction to yield $\mathrm{OH}$-end group: HO-PDMAEMA-Br (A-1, blue), HO-PDMAEMA-N 3 (A-2, red) and $\mathrm{HO}-\mathrm{PDMAEMA}-\mathrm{OH}$ (A-3, black).

from the desired triblocks, utilising techniques such as: precipitation in different solvents, preparative SEC and ultrafiltration. However, all SEC traces of samples from the different purification techniques had the same appearance, i.e., the apparent bimodality remained. This is illustrated in Fig. 7 where all fractions from preparative SEC are displayed with an offset in intensity. The appearance of the SEC trace is independent of the separation technique, which indicates that the bimodality in the SEC traces is not caused by a mixture of diand triblocks but an effect of a physical phenomenon occurring during SEC analysis.

It has previously been stated that analysing PDMAEMA with THF SEC is difficult due to the potential adsorption of PDMAEMA onto the columns, giving rise to broadening of the peak (higher $D_{\mathrm{M}}$ ) and lower elution volume (higher molecular weight $\left.\left(M_{\mathrm{w}}\right)\right)^{55}$ Additionally, PDMAEMA is a thermoresponsive 


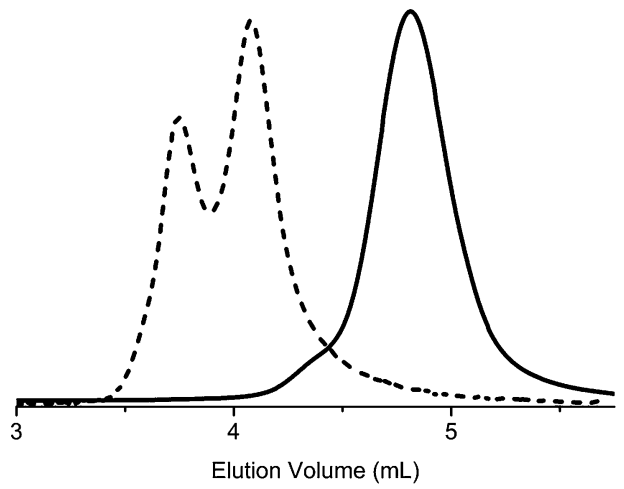

Fig. 6 DMF-SEC traces of HO-PDMAEMA-OH (A-3, solid line) and triblock PCL- $b$-PDMAEMA- $b-P C L$ (BAB, dashed line).

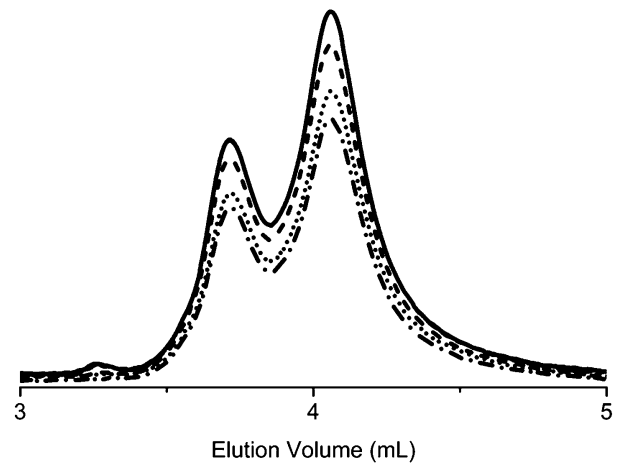

Fig. 7 DMF-SEC traces of all fractions from preparative SEC of PCL- $b-$ PDMAEMA- $b-P C L$ (BAB).

polymer, exhibiting a lower critical solution temperature (LCST) in a temperature range of $38-80{ }^{\circ} \mathrm{C}$ in water depending on pH. ${ }^{56,57}$ Even though the mobile phase of the SEC system was DMF, this thermoresponsive behaviour could cause possible agglomeration since the SEC system was operated at $50^{\circ} \mathrm{C}$ and DMF, as water, has the ability to form hydrogen bonds that can interact with PDMAEMA. ${ }^{58}$ To investigate the temperature dependence, DLS measurements were performed in DMF + 0.01 $\mathrm{M} \mathrm{LiBr}$, the solvent used for SEC, at $25{ }^{\circ} \mathrm{C}$ and $50{ }^{\circ} \mathrm{C}$, as well as during heating in between those two temperatures, and it was found that the sizes of the spontaneously formed micelle-type structures varied for triblock BAB between 5-10 nm up to 5000 $\mathrm{nm}$ with increasing temperature (Fig. S3†).

Therefore, it is believed that the bimodal character of the trace in SEC (Fig. 6) for BAB is a phenomenon, not reflecting true values for $D_{\mathrm{M}}$ and/or $M_{\mathrm{n}}$, caused by plausible interaction with the SEC columns in combination with, and possibly enhanced by, temperature-induced agglomeration in the solvent used for the SEC analysis. Hence, it could be concluded that the targeted product, i.e. the triblock, had been obtained.

On the other hand, triblock ABA had a monomodal, slightly tailed, trace in SEC. Consequently, the fact that only a minor variation in size with temperature in DLS was observed was expected (Fig. S3†). It is, therefore, hypothesized that the temperature-induced effect in SEC and strong column

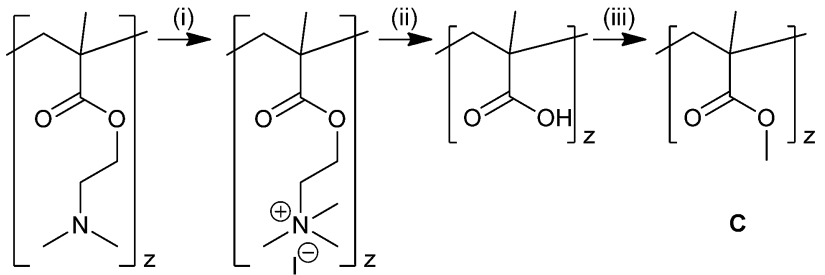

Scheme 3 Conversion of PDMAEMA into PMMA (C). Reagents and conditions: (i) Mel, $\mathrm{THF}, 25^{\circ} \mathrm{C}$; (ii) $\mathrm{NaOH} / \mathrm{H}_{2} \mathrm{O}, \mathrm{HCl}, 90{ }^{\circ} \mathrm{C}$; (iii) trimethyldiazomethane solution, $\mathrm{THF}, \mathrm{H}_{2} \mathrm{O}, 25^{\circ} \mathrm{C}$.

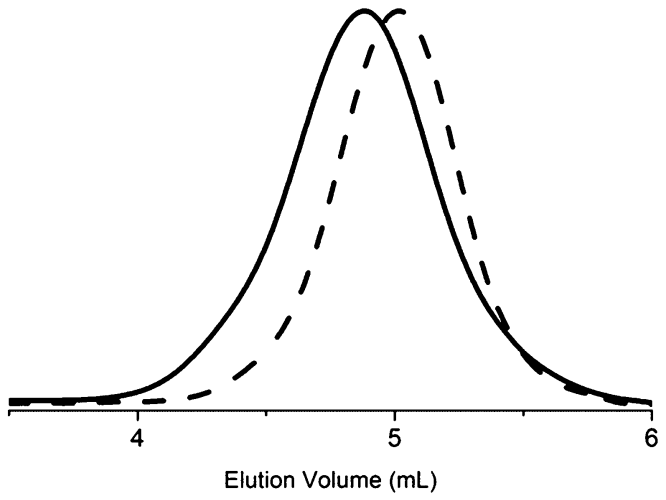

Fig. 8 DMF-SEC traces of PDMAEMA before (solid line) and after conversion into PMMA (dashed line).

interactions, yielding traces not reflecting true values for $D_{\mathrm{M}}$ and/or $M_{\mathrm{w}}$, is more pronounced with PDMAEMA being the middle block.

To further investigate the behaviour of PDMAEMA in SEC, the PDMAEMA was converted into PMMA (Scheme 3, C), through quaternisation, alkaline hydrolysis and subsequent methylation, allowing SEC analysis without plausible adsorption to columns or thermoresponsive behaviour. In Fig. 8 the DMF SEC (calibrated against PMMA) traces of PDMAEMA and the corresponding PMMA are displayed.

The molecular weight was, as expected, somewhat lower, $5800 \mathrm{~g} \mathrm{~mol}^{-1}$ as compared with $7100 \mathrm{~g} \mathrm{~mol}^{-1}$ prior to conversion, since $M_{\mathrm{w}}$ of MMA is lower than that of DMAEMA and in theory the conversion should yield a PMMA with a $M_{\mathrm{w}}$ of $4500 \mathrm{~g}$ $\mathrm{mol}^{-1}$. The $D_{\mathrm{M}}$, on the other hand, was substantially lower, decreasing from 1.27 to 1.07 , a difference ascribed to the influence of the dimethylamino group of PDMAEMA. This concludes that analysing PDMAEMA, or block copolymers of it, with DMF SEC at $50{ }^{\circ} \mathrm{C}$ gives a trace that to a greater extent compared with other linear polymers lacking this group, does not reflect the actual molecular weight and/or distribution.

PCL is a semicrystalline polymer with a glass transition temperature $\left(T_{\mathrm{g}}\right)$ of around $-60{ }^{\circ} \mathrm{C}$ (ref. 59) and a melting temperature $\left(T_{\mathrm{m}}\right)$ of around $60{ }^{\circ} \mathrm{C},{ }^{60}$ while PDMAEMA is an amorphous polymer with a $T_{\mathrm{g}}$ of around $10{ }^{\circ} \mathrm{C} .{ }^{61}$ The thermal properties of the macroinitiators and triblock copolymers were investigated with DSC, and the results are compiled in Table 2. 
Table 2 Summary of results from thermal analysis with DSC

\begin{tabular}{llll}
\hline Polymer & $T_{\mathrm{g}}\left({ }^{\circ} \mathrm{C}\right)$ & $T_{\mathrm{m}}\left({ }^{\circ} \mathrm{C}\right)$ & $\mathrm{X}_{\mathrm{c}} \mathrm{PCL}^{a}(\%)$ \\
\hline B & -67.6 & 54.2 & 56.6 \\
ABA & -27.0 & - & - \\
A-3 & 4.3 & - & - \\
BAB & -67.4 and -5.7 & 57.2 & 48.8
\end{tabular}

${ }^{a}$ Determined from DSC according to eqn (1) and in the case of $\mathbf{B A B}$ normalised to weight fraction of PCL determined from ${ }^{1} \mathrm{H}-\mathrm{NMR}$.

As expected, B exhibited a low $T_{\mathrm{g}}$ and a high crystallinity, close to the reported values for PCL. However, after formation of ABA the inherent crystallinity of PCL disappears while the $T_{\mathrm{g}}$ is increased, which is ascribed to the inherent characteristics of PDMAEMA. It is assumed that PDMAEMA prevents crystallisation, at the same time as it gives rise to a different packing of the polymer chains compared with the one that existed in $\mathbf{B}$, yielding a higher $T_{\mathrm{g}}$. From the Fox equation [eqn (2)], the weight fraction of PCL was estimated to be $36 \%$, which is in line with ${ }^{1} \mathrm{H}$-NMR estimation since it would be equivalent to a total molecular weight of $22300 \mathrm{~g} \mathrm{~mol}^{-1}$. The thermal properties of A-3, no crystallinity and a $T_{\mathrm{g}}$ in the vicinity of $10{ }^{\circ} \mathrm{C}$, are characteristic of the PDMAEMA homopolymer. In previous work, diblock copolymers of PCL and PDMAEMA were prepared and DSC analysis showed that they exhibited semi-crystallinity arising from the PCL block. Hence, the conclusion can therefore be drawn that it is the architecture of ABA triblock copolymer that obstructs crystallinity. On the other hand, in triblock BAB where PDMAEMA is the central block, a phase separation can be observed since there are two $T_{\mathrm{g}}$ 's detected: one close to the $T_{\mathrm{g}}$ for B and one close to that for A-3. As a consequence, the Fox equation cannot be applied. Nevertheless, the inherent characteristics of PCL are pronounced in the form of exhibiting crystallinity and melting. Even though the crystallinity is slightly lower compared with PCL, B, it shows that the molecular architecture of these types of block copolymers is of high importance when tuning the degree of crystallinity/morphology.

\section{Conclusions}

Two types of triblocks of PDMAEMA and PCL have been prepared, ABA and BAB. PDMAEMA- $b$-PCL- $b$-PDMAEMA (ABA) was obtained through $\mathrm{Sn}(\mathrm{Oct})_{2}$-catalysed ROP of $\varepsilon$-CL followed by end-group transformation and $\mathrm{Cu}(\mathrm{I}) \mathrm{Cl} / \mathrm{HMTETA}$ mediated ATRP of DMAEMA. PCL- $b$-PDMAEMA- $b$-PCL (BAB) was synthesised by ATRP of DMAEMA followed by end-group conversion through azide-alkyne "click" chemistry and subsequent ROP of $\varepsilon$-CL. All samples were analysed by size exclusion chromatography where it was found that the evaluation of PDMAEMA-containing polymers was difficult due to the thermoresponsivity of PDMAEMA, affecting the solubility of the polymer in the temperature range at which the SEC was operated. From thermal analysis it was determined that the triblocks mainly exhibited the character of the outer blocks; in PDMAEMA- $b$-PCL- $b$-PDMAEMA the inherent crystallinity of PCL was not present, and in PCL- $b$-PDMAEMA- $b$-PCL the crystallinity was approximately as high as for neat PCL.

\section{Acknowledgements}

BiMaC Innovation and NordForsk Researcher Network are acknowledged for financial support.

\section{Notes and references}

1 J.-S. Wang and K. Matyjaszewski, Macromolecules, 1995, 28, 7901-7910.

2 H. Arslan, A. Pfaff, Y. Lu, P. Stepanek and A. H. Müller, Macromol. Biosci., 2013, 14, 81-91.

3 A. M. Alhoranta, J. K. Lehtinen, A. O. Urtti, S. J. Butcher, V. O. Aseyev and H. J. Tenhu, Biomacromolecules, 2011, 12, 3213-3222.

4 D. M. Haddleton, C. B. Jasieczek, M. J. Hannon and A. J. Shooter, Macromolecules, 1997, 30, 2190-2193.

5 N. M. L. Hansen, D. M. Haddleton and S. Hvilsted, J. Polym. Sci., Part A: Polym. Chem., 2007, 45, 5770-5780.

6 A. de Cuendias, M. Le Hellaye, S. Lecommandoux, E. Cloutet and H. Cramail, J. Mater. Chem., 2005, 15, 3264-3267.

7 K. Jankova, M. Bednarek and S. Hvilsted, J. Polym. Sci., Part A: Polym. Chem., 2005, 43, 3748-3759.

8 I. Javakhishvili, K. Jankova and S. Hvilsted, Polym. Chem., 2013, 4, 662-668.

9 L. Valtola, A. Koponen, M. Karesoja, S. Hietala, A. Laukkanen, H. Tenhu and P. Denifl, Polymer, 2009, 50, 3103-3110.

10 K. Jankova and S. Hvilsted, Macromolecules, 2003, 36, 17531758.

11 A. Kajiwara, K. Matyjaszewski and M. Kamachi, Macromolecules, 1998, 31, 5695-5701.

12 K. Matyjaszewski, Y. Nakagawa and S. G. Gaynor, Macromol. Rapid Commun., 1997, 18, 1057-1066.

13 K. Yu, L. Zhang and A. Eisenberg, Langmuir, 1996, 12, 59805984.

14 S. E. Webber, J. Phys. Chem. B, 1998, 102, 2618-2626.

15 F. Checot, A. Brulet, J. Oberdisse, Y. Gnanou, O. MondainMonval and S. Lecommandoux, Langmuir, 2005, 21, 43084315.

16 R. Savic, A. Eisenberg and D. Maysinger, J. Drug Targeting, 2006, 14, 343-355.

17 C. Porsch, Y. Zhang, Å. Östlund, P. Damberg, C. Ducani, E. Malmström and A. M. Nyström, Part. Part. Syst. Charact., 2013, 30, 381-390.

18 M. R. Talingting, Y. Ma, C. Simmons and S. E. Webber, Langmuir, 2000, 16, 862-865.

19 J. Li, W.-D. He and X.-L. Sun, J. Polym. Sci., Part A: Polym. Chem., 2007, 45, 5156-5163.

20 G. S. Kwon and K. Kataoka, Adv. Drug Delivery Rev., 1995, 16, 295-309.

21 O. Colombani, M. Ruppel, F. Schubert, H. Zettl, D. V. Pergushov and A. H. E. Mueller, Macromolecules, 2007, 40, 4338-4350. 
22 F. Kohori, K. Sakai, T. Aoyagi, M. Yokoyama, Y. Sakurai and T. Okano, J. Controlled Release, 1998, 55, 87-98.

23 W. Agut, A. Brulet, C. Schatz, D. Taton and S. Lecommandoux, Langmuir, 2010, 26, 10546-10554.

$24 \mathrm{~W}$. Agut, D. Taton and S. Lecommandoux, Macromolecules, 2007, 40, 5653-5661.

25 J. Gensel, E. Betthausen, C. Hasenöhrl, K. Trenkenschuh, M. Hund, F. Boulmedais, P. Schaaf, A. H. E. Müller and A. Fery, Soft Matter, 2011, 7, 11144-11153.

26 A. P. Narrainen, S. Pascual and D. M. Haddleton, J. Polym. Sci., Part A: Polym. Chem., 2002, 40, 439-450.

27 F. L. Baines, N. C. Billingham and S. P. Armes, Macromolecules, 1996, 29, 3416-3420.

28 X. Zhang and K. Matyjaszewski, Macromolecules, 1999, 32, 1763-1766.

29 P. van de Wetering, N. J. Zuidam, M. J. van Steenbergen, O. A. G. J. van der Houwen, W. J. M. Underberg and W. E. Hennink, Macromolecules, 1998, 31, 8063-8068.

30 T. Endo, Y. Shibasaki and F. Sanda, J. Polym. Sci., Part A: Polym. Chem., 2002, 40, 2190-2198.

31 I. Javakhishvili, W. H. Binder, S. Tanner and S. Hvilsted, Polym. Chem., 2010, 1, 506-513.

32 I. Javakhishvili and S. Hvilsted, Polym. Chem., 2010, 1, 16501661.

33 M. V. Walter, P. Lundberg, D. Hult, A. Hult and M. Malkoch, Polym. Chem., 2013, 4, 2680-2690.

34 H. Lönnberg, L. Fogelström, Q. Zhou, A. Hult, L. Berglund and E. Malmström, Compos. Sci. Technol., 2011, 71, 9-12.

35 H. Lönnberg, K. Larsson, T. Lindström, A. Hult and E. Malmström, ACS Appl. Mater. Interfaces, 2011, 3, 14261433.

36 N. Nordgren, L. Carlsson, H. Blomberg, A. Carlmark, E. Malmström and M. W. Rutland, Biomacromolecules, 2013, 14, 1003-1009.

37 F. Bougard, M. Jeusette, L. Mespouille, P. Dubois and R. Lazzaroni, Langmuir, 2007, 23, 2339-2345.

38 L. Mespouille, M. Vachaudez, F. Suriano, P. Gerbaux, O. Coulembier, P. Degée, R. Flammang and P. Dubois, Macromol. Rapid Commun., 2007, 28, 2151-2158.

39 S. Utsel, C. Bruce, T. Pettersson, L. Fogelström, A. Carlmark, E. Malmström and L. Wågberg, ACS Appl. Mater. Interfaces, 2012, 4, 6796-6807.

40 S. Motala-Timol and D. Jhurry, Eur. Polym. J., 2007, 43, 30423049.
41 C. Zhu, S. Jung, S. Luo, F. Meng, X. Zhu, T. G. Park and Z. Zhong, Biomaterials, 2010, 31, 2408-2416.

42 G. Siqueira, J. Bras and A. Dufresne, Polymer, 2010, 2, 728765.

43 D. Klemm, F. Kramer, S. Moritz, T. Lindstrom, M. Ankerfors, D. Gray and A. Dorris, Angew. Chem., Int. Ed. Engl., 2011, 50, 5438-5466.

44 A. K. Bledzki and J. Gassan, Prog. Polym. Sci., 1999, 24, 221274.

45 J. George, M. S. Sreekala and S. Thomas, Polym. Eng. Sci., 2001, 41, 1471-1485.

46 V. Coessens and K. Matyjaszewski, J. Macromol. Sci., Part A: Pure Appl. Chem., 1999, 36, 667-679.

47 R. Huisgen, G. Szeimies and L. Moebius, Chem. Ber., 1967, 100, 2494-2507.

48 H. C. Kolb, M. G. Finn and K. B. Sharpless, Angew. Chem., Int. Ed., 2001, 40, 2004-2021.

49 B. Wunderlich, Macromolecular Physics, Academic Press, New York, 1980, vol. 3, Crystal Melting.

50 T. G. Fox, Bull. Am. Phys. Soc., 1956, 1, 123.

51 R. A. Cordeiro, N. Rocha, J. P. Mendes, K. Matyjaszewski, T. Guliashvili, A. C. Serra and J. F. J. Coelho, Polym. Chem., 2013, 4, 3088-3097.

52 F. A. Plamper, A. Schmalz, E. Penott-Chang, M. Drechsler, A. Jusufi, M. Ballauff and A. H. E. Müller, Macromolecules, 2007, 40, 5689-5697.

53 J. Huang, R. R. Koepsel, H. Murata, W. Wu, S. B. Lee, T. Kowalewski, A. J. Russell and K. Matyjaszewski, Langmuir, 2008, 24, 6785-6795.

54 N. V. Tsarevsky, S. A. Bencherif and K. Matyjaszewski, Macromolecules, 2007, 40, 4439-4445.

55 A. P. Narrainen, S. Pascual and D. M. Haddleton, J. Polym. Sci., Part A: Polym. Chem., 2002, 40, 439-450.

56 J. Niskanen, C. Wu, M. Ostrowski, G. G. Fuller, S. Hietala and H. Tenhu, Macromolecules, 2013, 46, 2331-2340.

57 F. A. Plamper, M. Ruppel, A. Schmalz, O. Borisov, M. Ballauff and A. H. E. Müller, Macromolecules, 2007, 40, 8361-8366.

58 Y. J. Chang and E. W. Castner, J. Chem. Phys., 1993, 99, 113125.

59 C. Allen, D. Maysinger and A. Eisenberg, Colloids Surf., B, 1999, 16, 3-27.

60 E. Núñez, C. Ferrando, E. Malmström, H. Claesson, P. E. Werner and U. W. Gedde, Polymer, 2004, 45, 5251-5263.

61 R. L. Teoh, K. B. Guice and Y.-L. Loo, Macromolecules, 2006, 39, 8609-8615. 